\title{
Exploration of Bias Effects in Oil and Water Through Visual Communication of Expression Photography
}

\author{
Sigit Setya Kusuma ${ }^{1}$, Elin Herlina ${ }^{2}$, Feby Fajar Nugraha ${ }^{3}$ \\ ${ }^{1}$ Visual Communication Design, Universitas Kuningan, ${ }^{2}$ Primary Teacher Education, Universitas \\ Kuningan \\ \{sigit.setya@uniku.ac.id\}
}

\begin{abstract}
The research as well as the creation that has been made is "Exploration of the Effects of Bias on Oil and Water through Visual Communication Expression Photography". This research has the objectives, namely: Presenting a new style in research and a photographic work with a mixture of oil and water objects. Harmonizing the mixture of oil and water in photography, so as to produce colors and shapes that are used as a new creative medium to express emotions, ideas and concepts that can be manifested in a unique, unique, beautiful, interesting and imaginative photographic creation. The research this time is looking for creative ideas or extracting something that has not been seen and then raised. Oil and water present the effect of light refraction on a mixture of oil and water through photographic experimentation, the effect of refraction is the bending of light when light passes through the boundary plane of two mediums with different refractive index. Oil and water are the same substance, which is a liquid but have different molecules, so oil and water cannot be combined. The differences that cannot be put together become interesting things when visualized through the media of photography. The result of this research is a work of photography which is a process of knowledge about the creative process of making an art photography work. Besides being conceptually mature, they can have artistic experience about photography. Her interest in the choice of oil and water objects is a challenge in itself how this visualization can be communicated through expression photography and producing artistic photos
\end{abstract}

Keywords: Bias Effects; Visual Communication; photography

\section{Introduction}

A photographic work can be said to be abstract as is the case with other works of art if the object displayed is not real and it is difficult to recognize the shape of the object's appearance, even though it is also the result of a recording of what is in the natural surroundings. The main problem is the extent to which the work can represent the photographer's goals and concepts in an effort to present his photographic work as a reflection of what was planned and expected before the work itself (Soedjono, 1999: 53). Refraction of light is the bending of light when the light beam passes through the boundary plane of two mediums with different refractive indexes, the refraction of light causes false depth and perfect reflection (Saeful Karim, 2008: 291). The beam of light from the air that enters the glass will experience a bend. This event is called light refraction.

Oil and water are used as objects for the creation of photographic works because of the same nature of a substance but with different masses and cannot be put together. As in philosophy, all humans are the same, but every human being has differences, from these 
differences that can make a harmonious unity. The phenomenon of oil and water represents a symbol of a difference that can become a harmonious whole. In addition, oil and water retain the beauty that is captured by cameras and lenses so that they have an unexpected effect with the combination of playing lighting. The details and shapes of oil and water can create multiple interpretations depending on who is looking and observing, only by changing the point of view that is different from the usual and giving a little in-depth observation. According to the theory in the branch of chemistry, a science of objects and their changing processes which are viewed based on the arrangement and properties of the atoms or molecules that make them up, every substance will dissolve in water because they have something in common, but water and oil are not so. Water consists of small molecules with a weight of three, namely 2 hydrogens and 1 oxygen, while oil consists of large molecules, namely carbon and hydrogen without oxygen at all (Poedjiadi, 1994:1).

This time, this photography creation with oil and water objects shows a difference from the creation in his previous works. The creation of this work displays the effect of refracting light from a background by means of the background being kept behind an aquarium, or a glass filled with oil and water liquid, this reflection or refraction is called the bias effect. The refractive effect of light is the bending of light when the light beam passes through the boundary plane of two mediums with different refractive indexes, the refraction of light causes false depth and perfect reflection (Saeful Karim, 2008: 291).

The beam of light from the air that enters the glass will experience a bend. This event is called an optical illusion or light bias effect. Photography is a form of non-verbal communication, namely communication using images. Communication in photography is of course very important, because a photo is produced to communicate a work with the audience or the audience who sees a photo work. Communication is a process of delivering information (messages, ideas, ideas) from one party to another. In general, communication is done verbally or verbally which can be understood by both parties. A work of art not only provides valuable knowledge and experience for life, because it also has aesthetic value. Aesthetics is a science that studies everything related to beauty, studying all aspects of what we call beauty or beauty (Djelantik, 1999:9).

\section{Method}

Photography requires a mature concept; the artistic side cannot be ignored. Likewise, with the selection of materials and models to be used. Photography also requires deep observation as well as exploration as a work of art photography. The following are the stages of creating a photographic work "Exploration of the Effects of Bias on Oil and Water through Photographic Visual Communication".

\subsection{Observation Method}

\subsubsection{Compiling the Design of Creation}

The creation designs that need to be done in the creation of photographic works include:

a. Topic Selection. The topic in question is a main topic or subject matter in a research. Selection of topic on "Exploring the Effects of Bias on Oil and Water through Photographic Visual Communication".

b. Reading Literature, after the topic selection process has been carried out, then make questions that are in accordance with the research topic. Looking for references from existing works that have the same object in order to enrich references and information 


\subsubsection{Research Location / Creation}

The location of the object of creation in this study is in a mini studio.

\subsection{Exploration}

Before the work execution process begins, there are several things that need to be done, including:

a. Select Oil and Water objects

Choosing oil objects to be used for exploration, namely oil, gasoline and cooking oil, the stage of selecting oil in this exploration is important so that the results of exploration will be able to determine what oil to use. The water object that will be used is of course mineral water, mineral water has neutral properties so that later in the photo shoot can bring out interesting ordinary effects.

b. Data collection

Data collection is the most important stage in a creation. Collection can be done by various methods such as: exploration, observation, object selection, and literature study. This activity is carried out in essence to obtain data or information that is really needed. The exploration process is carried out in shooting and forming the pedosphere through a stitching technique process. Furthermore, in the next stage, it is carried out by literature study by reading books or the theory of beauty which discusses art photography and pedosphere photography.

\subsection{Experiment}

\subsubsection{ISO selection}

ISO is an International Standard Organization. By defining ISO is a measure of the level of the camera sensor to light. The higher the ISO setting, the more sensitive it is to light, whereas the lower the ISO number the lower the light sensitivity will be. So the ISO selection is indeed the lighting when shooting takes place.

\subsubsection{Sharp Room}

The sharp space or better known as the depth of field in photography is determined based on the selection of the diaphragm on the camera, the distance between the camera and the object, the focal length, and in the editing process. Sharp space greatly affects the focus of interest in a photo work. So, a photographer must be able to determine the sharp space when executing the work.

\subsubsection{Formation}

Photo works that have been selected or selected then carry out stitching techniques using Adobe Photoshop CC 2018. The processing is carried out by assembling all the photos that have been shot into one circle with one unit, further processing is limited to processing level changes, brightness, cropping and selective color.

\section{Result and Discussion}

In the work entitled "Fresh Oranges", it is almost the same as the third work which is inspired by Disney cartoon films featuring huge fruits and being attacked by wild animals. This work presents an experiment of oil and water with a refractory yellow color emanating from citrus fruits. The yellow color displays the same brightness and freshness as an orange, which is a fruit that feels fresh when eaten. Oranges are taken as a refraction because it is a 
commonly known fruit and is widely consumed by people. Citrus fruits are attractive to be used as refraction in terms of the texture of the citrus fruit itself. In this work there is a spider animal whose aim is that it is not monotonous to see in this work of oil and water exploration. The refractive effect of oil and water produces a distortion effect on the refractive medium, namely citrus, so that the refractive media which enters the oil and water becomes bubbling following the shape of the oil and water.

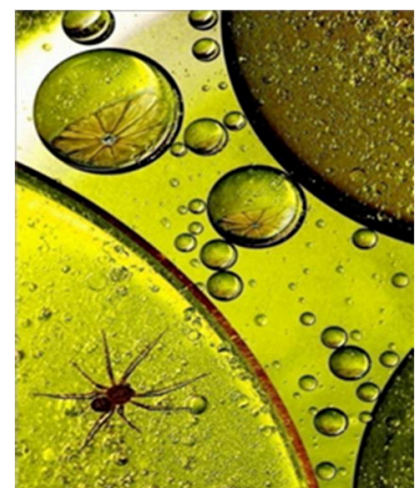

Fig 1. Photo of work 1 Title of Work: "Fresh Oranges"

The type of oil used is cooking oil because cooking oil has transparency properties so it can absorb the refractive effect of light well. Macro photography techniques support the results of oil and water exploration. Because with the macro photography technique, the object of the refraction effect of oil and water will appear clear and detailed. Because without the help of macro photography techniques with the naked eye seeing the mixing of oil and water looks normal, macro photography aims to enlarge small objects into large and detailed.

\subsection{Photo shooting scheme 1}

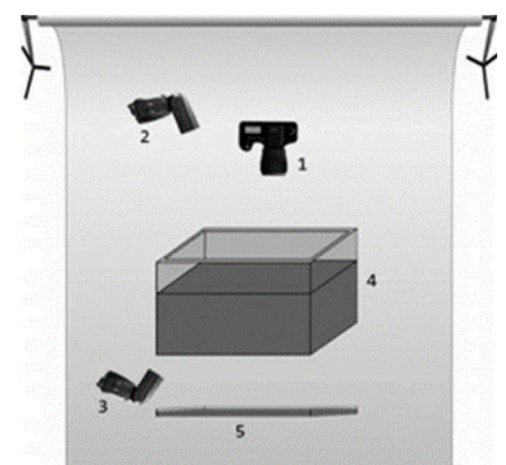

Scheme Review:

Fig 2. Photo Shooting Scheme 1.
a. Camera
b. Top left light
c. Right bottom light
d. Aquarium
e. Media of refraction 
In this shooting process is done indoors with a mini studio photography equipment using two flashlights and an aquarium. In the photo scheme four, you can see the position of the shooting process that looks like the aquarium is in the middle position, the camera is in the top position of the aquarium with a distance of $40 \mathrm{~cm}$ from the aquarium, the media can be under the aquarium, one flash is in the lower left position of the aquarium and one flash is above the left aquarium. A flash or assist light in the lower position of the aquarium directed at $225 \mathrm{o}$ from the shooting point towards the aquarium intends to illuminate the oranges that are in the oil and water mixture so that the orange texture is clear.

The second flash is above the left of the aquarium with the direction of the position 3160 aims to even out the light clearly in oil and water objects with the effect of light refraction. The position of the distance the direction of the light can change with the short distance. The closer the light to the object the harder the light produced, the more the farther away the light the softer the light produced.

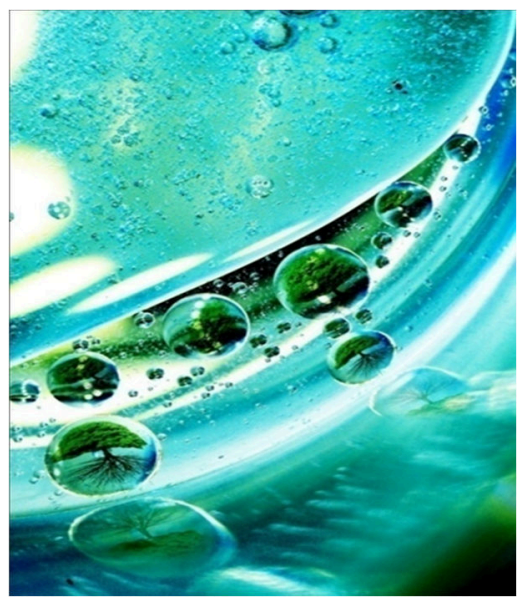

Fig 3. Photo of work 2 Title of Work: "Green the Earth"

The exploration of oil and water in the title of the work "Green the Earth" provides an interesting form of hoping that the earth will always have greenness to enjoy fresh oxygen, when the oil and water experiment which forms spheres displays a reflection of the spheres with the refraction of green and shady trees. In the making of this work, there is less and less persistence in reforestation in nature. Everyone wants freshness, wants beauty and that's all it needs with greening, let's green the earth, green nature with self-awareness. Let's keep the land, let's take care of this earth and let's protect this nature. Oil and water are in the form of spheres and the refraction from the tree enters the sphere so that the shady trees that enter the refraction experience distortion following the circles in the oil and water.

The effect of refraction on oil and water produces a distortion effect on the refractive medium, namely shady trees, so that the refractive media that enters the oil and water becomes bubbling following the shape of the oil and water. The type of oil used is cooking oil because cooking oil has transparency properties so it can absorb the refractive effect of light well. Macro photography techniques support the results of oil and water exploration. Because with the macro photography technique, the object of the refraction effect of oil and water will appear clear and detailed. Because without the help of macro photography techniques with the 
naked eye seeing the mixing of oil and water looks ordinary, macro photography aims to enlarge small objects into large and detailed objects.

\subsection{Photo shooting scheme 2}

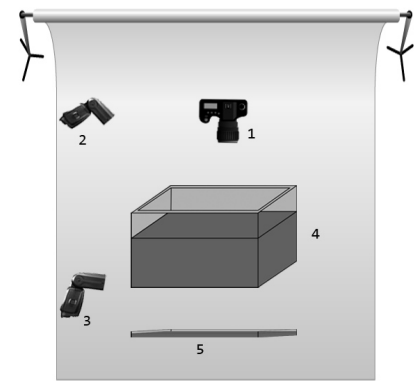

Fig 4. Photo Shooting Scheme 2

Scheme Review:

a. Camera

b. Top left light

c. Lower left light

d. Aquarium

e. Media of refraction

In this shooting process is done indoors with a mini studio photography equipment using two flashlights and an aquarium. In the scheme of the twelve photos you can see the position of the shooting process that looks like the aquarium is in the middle position. The camera is in the top position of the aquarium with a distance of $40 \mathrm{~cm}$ from the aquarium and can change rarely far away according to how far or close objects of oil and water are in the aquarium with the bias media under the aquarium. In the lighting technique one exposure is in the lower left position of the aquarium and one exposure is above the left of the aquarium.

The first light from the bottom position of the aquarium in the direction 2250 from the shooting point towards the aquarium intends to illuminate the mixture of oil and water and the medium of refraction. The second light is at top left of the aquarium with the direction of the position of 3160 aims to clearly distribute the light in oil and water objects with the effect of light refraction. The position of the distance the direction of the light can change with a short distance.

\section{Conclusion}

The effect of light refraction or refraction is the absorption of light in two medium spaces, namely glass and water, resulting in deflection with the refractive media starting at a position from $0 \mathrm{o}$ to $180 \mathrm{o}$, because it is a process of the effect of light refraction. The effect of refraction is used as an exploration in the creation of photographic works. Oil and water become interesting objects because oil and water change the point of view from natural human vision 
to visual photography. Oil and water hold beauty that not everyone knows, because basically oil and water are used by humans for various purposes. In the visualization of oil and water photography changes the perspective so that it has aesthetic value, how when seen by the naked eye oil and water does not feel attractive, but in visuals, oil and water photography becomes something beautiful. This happens because the aesthetic value that emanates from each work of art has its own uniqueness and characteristics which at the same time implies the aesthetic value it contains.

Art photos emphasize more on the aspects of art creation that contain beauty values that apply the principles of artistic creation in their work and hold the ideas and ideas of the photographer himself. The resulting effect of the refractive effect of light on a mixture of oil and water is light. Light is the main source of the process of creating photographic works because in the formation of the refractive effect of light on a mixture of oil and water, it is very influential. The light source affects the result of the formation of the oil and water mixture so that with the presence of a light source and several adjustments to the light direction, the ordinary effect and the mixture of oil and water produce interesting shapes. Experimentation of the refracting effect of mixing oil and water is a stage of finding or finding ideas and concepts in the creativity of creating photography.

Oil and water are used as objects for the creation of photographic works because of the same nature of a substance but with different masses and cannot be put together. As in philosophy, all humans are the same, but every human being has differences, from these differences that can make a harmonious unity. The phenomenon of oil and water represents a symbol of a difference that can become a harmonious unity, giving rise to multiple interpretations depending on who is seeing and observing, only by changing a different point of view than usual and giving a little in-depth observation.

\section{References}

[1] Arena, Syl. 2012.Lighting for Digital Photography. Jakarta. Prigel Books PT Serambi Ilmu Semesta

[2] Darmaprawira, Sulasmi. 2002. Warna, Teori dan Kreativitas Penggunaannya. Bandung. ITB.

[3] Darsono Sony Kartika. 2017. Seni Rupa Modern. Bandung: Penerbit Rekayasa Sains

[4] Djelantik A.A.M. 199. Estetika. Bandung: Penerbit Masyarakat Seni Pertunjukan Indonesia

[5] Feininger, Andreas. 1998. Unsur Utama Fotografi. Terjemahan Soelarko. Semarang: Dahara Prize.

[6] Marianto, M Dwi. 2006. Quantum Seni. Semarang: Dahara Prize.

[7] Marah, Risman. 2008. Soedjai Kartasasmita di Belantara Fotografi Indonesia. Yogyakarta: BP ISI Yogyakarta.

[8] Pudjaatmaka, A. Hadyana. 2002. Kimia. Jakarta: Penerbit PT Balai Pustaka dan Gramedia.

[9] Poedjiadi, Anna. 1994. Dasar-Dasar Biokimia. Jakarta: Penerbit Universitas Indonesia.

[10] Sadono, Sri. 2015. Komposisi Foto. Jakarta: PenerbitPT Elex Media Komputindo.

[11] Sarojo, Ganijanti Aby. 2007. Gelombang dan Optika. Jakarta: Penerbit Salemba Teknika.

[12] Soedjono, Soeprapto.2006. Pot Pourri Fotografi. Jakarta: UPT Trisakti.

[13] Soedjono, Soeprapto. 1999. Karya Fotografi Dalam Lingkup Seni Rupa. VII/01, BP. ISI, Yogyakarta.

[14] Sukarya, Deniek G. 2009. Kiat Sukses Deniek G. Sukarya dalam Fotografi dan Stok Foto. Jakarta: Elex Media Komputindo.

[15] Suyatno dkk. 2012. Dasar Kimia. Jakarta:Grasindo. 